\title{
PENGARUH PEMBELAJARAN TEMATIK-INTEGRATIF BERBASIS SOSIOKULTURAL TERHADAP HASIL BELAJAR PESERTA DIDIK KELAS III SEKOLAH DASAR
}

\author{
Slamet Arifin \\ PGSD Universitas Kuningan \\ masarifin.uniku@gmail.com
}

\begin{abstract}
This study aims to determine the effectiveness of the application of thematic learning model based integrative sosiokultural for students of class III Elementary School in Purbalingga. The research design was quasi experimental with one group pre-test and post-test design. The subject of research involved are students of class III SD N Pengadegan Pengadegan 1 and 2 a total of 56 students, where each class consists of 28 students. In this research, students of class III SD N Pengadegan 1 is determined as the control class (with thematic learning-integrative usual) and the third grade students of SD N Pengadegan 2 as the experimental class (using the model of thematic learningintegrative-based sociocultural. The results showed that there were differences the final results were significant between control classes using model-integrative thematic regular and classroom experiment that uses thematic learning model-based integrative socio-cultural. it is obtained from the t-test with $p<0.05$ then there is also a significant difference, namely with sig $=0.0006$.
\end{abstract}

Keywords: thematic-integrative, sociocultural based learning

\section{PENDAHULUAN}

Keberhasilan implementasi dari setiap kurikulum sangat bergantung bagaimana dengan guru menjalankann di lapangan. Guru sebagai ujung tombak dilapangan diharapkan mampu melaksanakan tugasnya dengan baik. Guru dituntut mampu merancang pembelajaran yang sesuai dengan Kurikulum 2013. Bukan hal yang mudah ketika harus menyesuaikan dengan sesuatu yang baru. Pada fase penyesuaian inilah guru mulai menemukan permasalahan dalam implementasi Kurikulum 2013. Salah satu permasalahan yang menjadikan implementasi Kurikulum 2013 kurang maksimal adalah proses difusi terhadap para guru sebagai pelaksana kurikulum dilapangan yang tidak berjalan secara baik. Jimmy Paat dalam sindonews menyatakan bahwa "yang menjadi persoalan, perubahan dari kurikulum lama ke
Kurikulum 2013 begitu cepat. Meskipun pemerintah mengklaim sudah melakukan kajian-kajian. Seharusnya kurikulum 2013 ini dilaksanakan di 2015 supaya para guru bisa dipersiapkan terlebih dahulu". Menanggapi hal tersebut peneliti sependapat bahwa proses difusi akan berjalan baik manakala guru mendapat pelatihan yang matang sebelum implementasi Kurikulum 2013 berlangsung. Waktu pelatihan yang singkat dirasa kurang bagi para guru untuk memahami ruh dari Kurikulum 2013. Guru sebagai pelaku utama di lapangan harus disiapkan dengan matang agar pelaksanaan kurikulum 2013 dapat berjalan sukses. Hidayat (2013:114) menyebutkan bahwa guru harus diposisikan sebagai "aktor utama" para guru harus disiapkan secara matang, mulai dari penysusunan rencana pembelajaran, 
pelaksanaan pembelajaran, penilaian, analisis, hingga tindak lanjutnya.

Mencermati pernyataan sebelumnya dapat disimpulkan bahwa yang terjadi di lapangan tidak berjalan sesuai dengan apa yang seharusnya sehingga, timbulah kesenjangan (permasalahan) dalam implementasi kurikulum 2013. Kesenjangan inilah yang kemudian memunculkan permasalahan lanjutan sebagai akibat persiapan yang kurang matang. Fakta di lapangan menunjukan bahwa banyak guru yang merasa belum paham betul dengan Kurikulum 2013. Permasalahan tersebut diakibatkan oleh waktu pelatihan yang begitu singkat dan setelah itu guru harus langsung menerapkan pembelajaran sesuai dengan Kurikulum 2013. Guru merasa bingung dalam merancang perencanaan pembelajaran pada aspek, pelaksanaan, dan penilaian terhadap peserta didik.

Pertama yang dirasakan oleh guru dalam implementasi Kurikulum 2013 adalah kurangnya pemahaman guru dalam merancang perencanaan pembelajaran.

Kurikulum 2013 mewajibkan guru untuk merancang pembelajaran dengan model tematik-integratif. Pembelajaran tematik sejatinya bukanlah hal yang baru bagi para guru Sekolah Dasar (SD). Pada Kurikulum Tingkat Satuan Pendidikan (KTSP) model pembelajaran tematik sudah diterapkan pada kelas I, II, dan III namun, pada kenyataannya masih banyak guru yang belum mengimplementasikan pembelajaran tematik dengan baik.

Suyanto (2013: 180) yang menyatakan bahwa pembelajaran tematik lebih menekankan pada keterlibatan peserta didik dalam proses belajar secara aktif dalam proses pembelajaran, sehingga peserta didik dapat memperoleh pengalaman langsung dan terlatih untuk dapat menemukan berbagai pengetahuan yang dipelajarinya.

Dari pernyataan tersebut dapat disimpulkan bahwa dengan model pembelajaran tematik-integratif proses belajar mengajar menjadi lebih menyenangkan (joyful) dan bermakna (meaningfull) bagi peserta didik. Selain diarahkan untuk terjadinya pembelajaran yang menyenangkan dan bermakna bagi peserta didik, guru dituntut untuk merancang pembelajaran yang mengintegrasikan nilainilai karakter dan nilai-nilai sosiokultural di lingkungan sekitar peserta didik berada. Pengintegrasian nilai-nilai karakter dan sosiokultural bermanfaat dalam upaya mengatasi masalah menurunnya nilai-nilai moral dan lunturnya jati diri bangsa. Sehingga, pada penelitian yang telah dilakukan menguji efektifitas pembelajaran tematik-integratif biasa dengan pembelajaran tematik-integratif berbasis sosiokultural di sekolah dasar.

Kegiatan pembelajaran merupakan proses membangun pengalaman yang dilakukan secara sistematis dan bertujuan untuk mengembangkan kemampuan peserta didik. Harapannya proses pembelajaran dapat dilakukan dengan lebih bermakna (meaningful learning) dan menyenangkan. Untuk menciptakan suatu pembelajaran yang lebih bermakna dalam Kurikulum 2013 dikenal model pembelajaran tematikintegratif. Model pembelajaran tematikintegratif bukanlah sesuatu yang baru dan asing bagi para guru di sekolah dasar, hal ini 
dikarenakan pada kurikulum yang berlaku sebelumnya sudah dikenal pembelajran tematik yang diterapkan di kelas rendah.

Suyanto (2013: 180) yang menyatakan bahwa pembelajaran tematik lebih menekankan pada keterlibatan peserta didik dalam proses belajar secara aktif dalam proses pembelajaran, sehingga peserta didik dapat memperoleh pengalaman langsung dan terlatih untuk dapat menemukan sendiri berbagai pengetahuan yang dipelajarinya. Pembelajaran tematik sebagai model pembelajaran termasuk salah satu tipe atau jenis model pembelajaran terpadu. Istilah model pembelajaran tematik pada dasarnya adalah model pembelajaran terpadu yang menggunakan tema untuk mengaitkan beberapa mata pelajaran sehingga dapat memberikan pengalaman yang bermakna kepada peserta didik (Depdiknas, 2006: 5). Hal ini sejalan dengan yang diungkapkan oleh Trianto (2012:57) yang menyebutkan bahwa pembelajaran terpadu dapat dikatakan sebagai pendekatan belajar mengajar yang melibatkan beberapa bidang studi untuk memberikan pengalaman bermakna kepada peserta didik.

Pembelajaran tematik-integratif dimaknai sebagai pembelajaran yang dirancang dan dikemas berdasarkan tematema tertentu. Dalam pembahasannya tema-tema ditinjau dari berbagai mata pelajaran. Pengintegrasian tersebut dilakukan dalam tiga hal, yaitu integrasi sikap, keterampilan dan pengetahuan. Salah satu model pengembangan pembelajaran tematikintegrtaif adalah model multidiciplinary Approach. Pembelajaran tematik yang dikembangan berdasarkan pada model multidisciplinary Approach mengintegrasikan berbagai bidang studi kedalam satu tema yang sesuai. Berikut adalah gambaran model pengembangan pembelajaran tematik antar bidang studi (Multidiciplinary Approach).

Pembelajaran berbasis sosiokultural merupakan pembelajaran yang mengintegrasikan nilai-nilai sosiokultural di dalam proses pembelajaran.

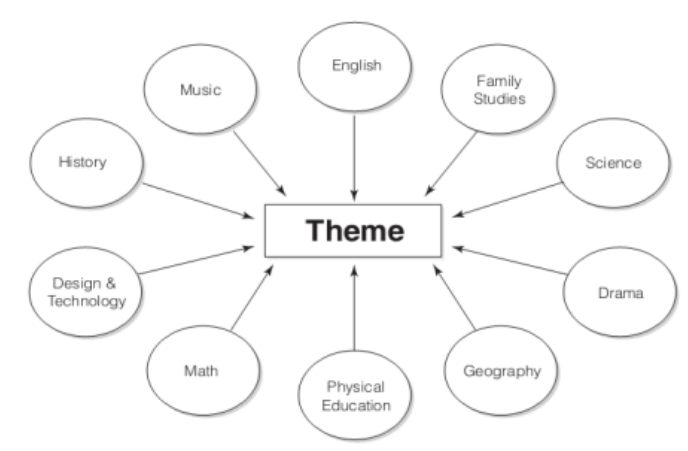

Gambar 1. Model Multidiciplinary Approach Darek \& Burns (2004: 9)

Nilai-nilai sosiokultural yang dimaksud adalah nilai-nilai budaya di sekitar lingkungan peserta didik. Sutarno (2007) menyatakan bahwa pemakaian budaya lokal (etnis) dalam pembelajaran sangat bermanfaat bagi pemaknaan dan proses hasil belajar, karena peserta didik mendapatkan pengalaman langsung yang bersifat kontekstual (titian tambang) dan bahan apersepsi untuk memahami konsep ilmu pengetahuan dalam budaya local (etnis). Dari pernyataan tersebut maka dapat kita cermati bahwa, dengan pembelajaran berbasisi sosiokultural pembelajaran akan lebih bermakna dikarenakan hal-hal yang diajarkan oleh guru bersifat kontekstual dengan nilainilai budaya sekitar.

Vigotsky (dalam Schunk, 2012: 243) mengungkapkan ada beberapa poin-poin utama yang harus diperhatikan terkait 
pandangannya mengegenai teori sosiokultural yaitu:

1. Social interactions are critical; knowledge is constructed between two or more people.

2. Self-regulation is developed through internalization (developing an internal representation) of actions and mental operations that occur in social interactions.

3. Human development occurs through the cultural transmission of tools (language, symbols)

4. Language is the most critical tool. Language develops from social speech, to private speech to covert (inner) speech.

5. The zone of proximal development (ZPD) is the difference between what children can do on their own and what they can do with assistance from others. Interactions with adults and peers in the $Z P D$ promote cognitive development.

Pandangan Vigotsky tersebut dapat dimaknai bahwa dalam teori sosiokultural, proses pembelajaran yang dialami peserta didik tidak bisa terlepas dari interaksi sosial dan penggunaan nilai dan simbol budaya lingkungan sekitar. Senada dengan kesimpulan tersebut Dikti (Sutarno, 2007) menyebutkan bahwa dalam pebelajaran berbasis sosiokultural nilai-nilai budaya diintegrasikan sebagai alat bagi proses belajar untuk memotivasi peserta didik dalam mengaplikasikan pengetahuan, bekerja secara kooperatif, dan mempresepsikan keterkaitan antara berbagai matapelajaran. Dari pernyataan tersebut dapat dicermati bahwa pembelajaran berbasis sosiokultural sangat relevan diterapkan dalam rangka menciptakan lingkungan belajar yang bermakna dan menyenangkan bagi peserta didik. Dari pernyataan tersebut maka apabila dikorelasikan dengan penerapan kurikulum 2013 akan sangat relevan, hal tersebut dikarenakan dalam kurikulum 2013 guru diharapkan mampu menciptakan pembelajaran yang lebih bermakna dan menyenangkan bagi peserta didik.

Sutarno (2007: 7-6) menyebutkan bahwa pembelajaran berbasis budaya dapat dibedakan menjadi empat macam, yaitu belajar tentang budaya, belajar dengan budaya, belajar melalui budaya dan belajar berbudaya. Berikut adalah penjelasan keempat macam hal yang telah disebutkan di atas:

1. Belajar tentang budaya

Belajar tentang budaya adalah menempatkan budaya sebagai bidang ilmu. Budaya dipelajari dalam program studi khusus, tentang budaya dan untuk budaya. Dalam hal ini budaya tidak terintegrasi dengan ilmu lain.

2. Belajar dengan budaya

Terjadi pada saat budaya diperkenalkan kepada siswa sebagai cara atau metode untuk mempelajarai pokok bahasan tertentu. Belajar dengan budaya meliputi pemanfaatan beragam bentuk perwujudan budaya. Dalam belajar dengan budaya, budaya dan perwujudan menjadi media pembelajaran dalam proses belajar, menjadi konteks penerapan prinsip atau prosedur dalam suatu mata pelajaran.

3. Belajar melalui budaya

Merupakan strategi yang memberikan kesempatan kepada siswa untuk menunjukan pencapaian pemahaman atau makna yang diciptakannya dalam suatau 
mata pelajaran melalui ragam perwujudan budaya.

4. Belajar berbudaya

Merupakan bentuk mengejawantah budaya itu dalam perilaku nyata seharihari siswa.

Berdasarkan pada uraian di atas maka dapat disimpulkan bahwa pembelajaran berbasis sosiokultural yang dimaksud dalam penelitian ini adalah pembelajaran yang mengintegrasikan nilai-nilai budaya setempat di dalam proses belajar mengajar serta melibatkan peserta didik dalam proses interaksi sosial guna mengkonstruksi pengetahuan peserta didik. Nilai-nilai sosial yang dimaksud adalah nilai-nilai moral budaya sekitar yang dijadikan sebagai nilainilai budaya yang harus dimiliki oleh peserta didik. Pengintegrasian nilai-nilai budaya setempat tercermin dalam penggunaan simbol-simbol budaya sebagai media pembelajaran yang sangat kontekstual dengan peserta didik. Proses pembelajaran berbasis sosiokultural tidak hanya dimaknai sebagai penggunaan simbol-simbol budaya sekitar sebagi media dalam pembelajaran namun juga proses pembelajaran yang menjadikan peserta didik belajar dengan budaya, belajar melalui budaya dan belajar berbudaya. Aspek sosiokultural yang diintegrasikan dalam perangkat pembelajaran yang dikembangkan adalah penggunaan media, sumber belajar yang merupakan hasil dari budaya lokal setempat.

Penelitian ini sejalan dengan beberapa penelitian lain yang mengangkat tema pembelajaran tematik. Liu dan Wang (2010) menunjukan hasil bahwa pembelajaran tematik berefek positif pada konsep pembelajaran peserta didik. Di samping itu, dalam penelitian ini juga ditemukan bahwa pembelajaran tematik menyediakan kerangka kerja bagi peserta didikyang dikembangkan dari konsep yang saling berkaitan dan menjadi model pembelajaran yang lebih stabil. Lebih jauh, ditemukan pula bahwa pembelajaran tematik cocok untuk para peserta didikyang memiliki kemampuan yang berbeda-beda.

Penelitian yang senada dilakukan oleh Sa'dun Akbar, I Wayan Sutama, dan Pujianto, (2006) ditemukan tingginya tingkat masalah atau kesulitan dalam pengembangan dan penerapan pembelajaran tematik untuk peserta didik SD kelas I dan II di Jawa Timur. Tingginya tingkat kesulitan tersebut diindikasikan oleh rata-rata skor dari pelaksanaan pembelajaran tematik untuk semua komponen permasalahan pengembangan dan penerapan bagi peserta didik SD kelas satu dan dua adalah 55, 48\%. Oleh karena itu, dikembangkan model pembelajaran tematik sebagai solusi untuk mengatasi permasalah yang ada. Hasil penelitian menunjukkan bahwa semua tema pembelajaran tematik yang dikembangkan valid baik menurut validator ahli maupun menurut validator paraktisi (guru di kelas).

Penelitan selanjutnya dilakukan oleh Min, Rashid, dan Nazri (2012) di Malaysia menemukan tingginya tingkat pemahaman keterampilan hidup terintegrasi guru terhadap pendekatan tematik. Ditemukan juga bahwa guru yang memahami keterampilan hidup terintegrasi sering menggunakan pendekatan tematik dalam mengajarkan keterampilan hidup terintegrasi. Ada hubungan signifikan antara tingkat pemahaman guru terhadap pendekatan tematik yang dipraktikkan secara 
tetap. Penelitian juga menunjukkan bahwa lamanya pengalaman guru dalam mengajar tidak secara signifikan berbeda dalam mempraktikakan pendekatan tematik.

Allahyar dan Ahmad. (2012) Dalam interaksi sosial, Vygotsky berpendapat, "ZPD"diciptakan. Dia menunjukkan bahwa perkembangan kognitif anak-anak juga terjadi melalui partisipasi dipandu dalam interaksi sosial dengan orang yang lebih berpengalaman, dengan alasan bahwa apa yang anak-anak dapat dilakukan dengan bantuan orang lain mungkin lebih menunjukkan perkembangan mental mereka daripada apa yang bisa mereka lakukan sendiri. Dia berpendapat bahwa kegiatan didukung sosial di ZPD terbangun dan memberikan jalan untuk pengembangan intelektual. Vygotsky percaya bahwa dalam interaksi sosial dengan orang tua, guru dan teman sebaya lebih mampu, anak-anak mencapai tujuan yang lebih tepat daripada yang mereka lakukan sendiri.

Dibandingkan dengan penelitian yang sudah ada sebelumnya, penelitian dan pengembangan yang dilakukan lebih menekankan pada pengintegrasian nilainilai sosiokultural dalam perangakat pembelajaran tematik-integratif kurikulum 2013 yang dikembangkan. Produk yang dihasilkan berupa silabus, RPP, Media dan Penilaian Hasil belajar sebagai penjabaran dari peragkat pembelajaran yang dikembangkan.

\section{METODE PENELITIAN}

Berdasarkan masalah dan tujuan penelitiannya, penelitian ini dirancang dalam bentuk penelitian Eksperimen kuasi (Quasi experiment) yaitu, melihat efektifitas penerapan pembelajaran tematik-integratif berbasis sosiokultural terhadap hasil belajar peserta didik sekolah dasar.

Prosedur penelitian dilakukan dengan menggunakan design Pretest- Posttest Control Group. Dimana dalam penelitian terdapat dua kelas yang dijadikan sebagai kelas perlakuan dan satu kelas dijadikan sebagai kelas kontrol. Berikut adalah design penelitian yang digunakan:

Tabel 1. Desain Pretest-Posttest Control Group

\begin{tabular}{c|c|c|c}
\hline Kelompok & $\begin{array}{c}\text { Pre- } \\
\text { test }\end{array}$ & Perlakuan & $\begin{array}{c}\text { Post- } \\
\text { Test }\end{array}$ \\
\hline Kontrol & $\mathrm{T}_{1}$ & $\mathrm{X}_{\mathrm{a}}$ & $\mathrm{T}_{3}$ \\
Eksperimen & $\mathrm{T}_{2}$ & $\mathrm{X}_{\mathrm{b}}$ & $\mathrm{T}_{4}$ \\
\hline
\end{tabular}

Keterangan:

$\mathrm{X}_{\mathrm{a}}=$ Pembelajaran menggunakan model pembelajaran normal.

$\mathrm{X}_{\mathrm{b}}=$ Pembelajaran menggunakan model tematik-integratif berbasis sosiokultural.

$\mathrm{T}_{1}=$ Tes kemampuan awal (pretest) kelas control

$\mathrm{T}_{2}=$ Tes kemampuan awal (posttest) kelas eksperimen

$\mathrm{T}_{3}=$ Tes kemampuan akhir (pretest) kelas control

$\mathrm{T}_{4}=$ Tes kemampuan akhir (pretest) kelas eksperimen

Subjek penelitian yang dilibatkan adalah peserta didik kelas III sekolah dasar di Kabupaten Purbalingga. Dimana subjek dipilih dari dua sekolah dasar yang memiliki karakteristik yang homogen. Teknik pengumpulan data yang digunakan dalam penelitian meliputi observasi dan tes. Instrumen penelitian yang digunakan meliputi 
instrumen lembar observasi keterlaksanaan pembelajaran dan tes hasil belajar.

Validitas instrumen yang digunakan dalam penelitian ini adalah menggunakan content validity. Dalam hal ini validitas dilakukan dengan melibatkan dua orang judgement untuk menilai relevansi instrumen penilaian dengan aspek-aspek yang hendak diukur.

\section{HASIL DAN PEMBAHASAN}

Penelitian dilakukan dengan melakukan pengujian terhadap dua rombongan belajar yang terdiri dari masing 28 orang peserta didik yang merupakan peserta didik-siswi kelas III sekolah dasar. Subjek penelitian adalah siswa kelas III SD N Pengadegan 1 dan SD N Pengadegan 2. Uji coba dilakukan pada tgl 12 s/d 17, Oktober 2015. Sebelum melakukan pembelajaran dengan model pembelajaran tematik integratif yang sudah dirancang oleh peneliti bersama dengan guru siswa diberi soal tes untuk mengukur kemampuan awal siswa (pre-test). Hasil tes ini kemudian diolah secara statistik dengan menggunakan SPSS 16 untuk menguji normalitas dan homogenitas data yang diperoleh (hasil uji normalitas dan homogenitas pada bagian selanjutnya). Secara lebih jelas hasil penelitian yang dilakukan tergambar pada pembahasan sesuai langkah-langkah sebagai berikut:

\section{Tahap Pra Perlakuan}

Sebelum diberikan perlakuan kepada kelas-kelas yang dijadikan subjek penelitian, seluruh subjek diberikan perlakuan berupa tes kemampuan awal yang ditujukan untuk mengukur kemampuan siswa. Berdasarkan hasil pengukuran nilai pre test siswa yang diambil sebagai subjek penelitian sebagai berikut.

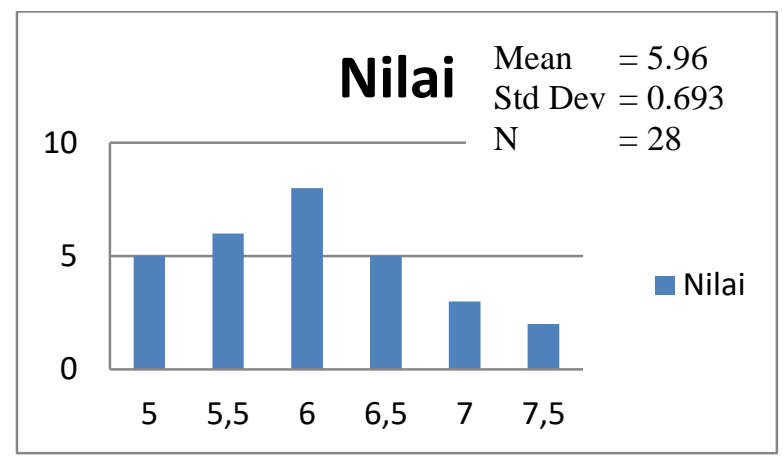

Gambar 2. Diagram Hasil Pre-test Kelas A

Berdasarkan Gambar tersebut dapat diketahui bahwa rata-rata hasil pre test kelas kontrol adalah 5.96, diari jumlah keseluruhan 28 siswa. Sedangkan hasil nilai pre-test siswa kelas perlakuan (eksperimen) menunjukan bahwa rata-rata skor yang diperoleh adalah:

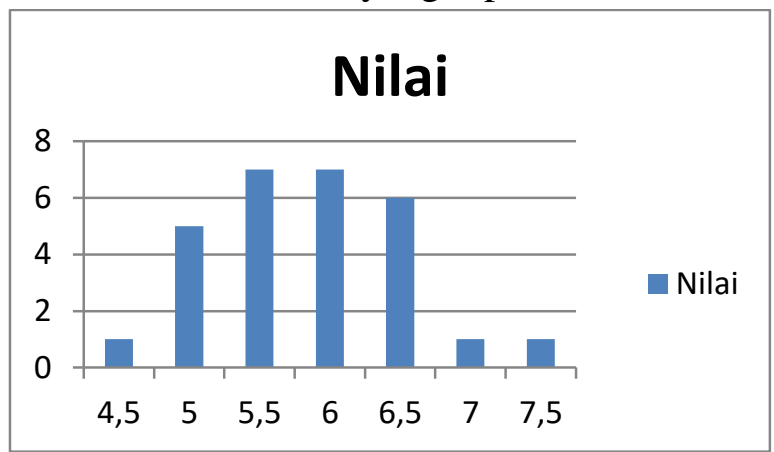

Gambar 3. Diagram Nilai Pre-test Kelas B

Berdasarkan hasil nilai pre-test siswa baik dari kelas kontrol dan kelas A dan B dimana diketahui rata-rata nilai untuk kelas $\mathrm{A}$ adalah 5.96 dan rata-rata nilai siswa kelas B adalah 5.84. Berdasarkan dari data tersebut maka peneliti secara sengaja menentukan kelas A sebagai kelas kontrol sedangkan kelas B sebagai kelas perlakuan (Treatment).

\section{Tahap Perlakuan}

Pada tahap ini penelitian dilanjutkan dengan memberikan perlakuan. Perlakuan diberikan kepada kelas-kelas yang sudah 
ditentukan, yaitu kelas Kontrol (siswa kelas III SD N Pengadegan 1) dan kelas eksperimen (siswa kelas III SD N Pengadegan 2). Kelas kontrol menggunakan model pembelajaran tematik seperti biasa sedangkan pada kelas eksperimen perlakuan yang diberikan adalah dengan menerapkan model pembelajaran tematik integratif berbasis sosiokultural. Pada tahap ini dilakukan juga kegiatan observasi, kegiatan ini dilakukan untuk mengapati proses pembelajaran yang dilakukan di kelas sudah sesuai dengan rencana pembelajaran yang ditentukan. Setelah diberi perlakuan pada masing-masing kelas diperoleh nilai post-test pada gambar 5:

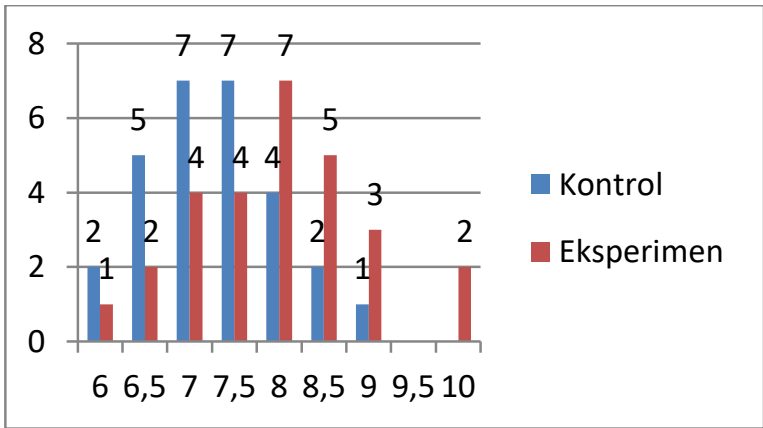

Gambar 5. Nilai Post-test Kelas Kontrol dan Ekperimen

Dari gambar di atas dapat diketahui bahwa nilai terendah post test kelas kontol adalah 6 dan nilai tertinggi adalah 9. Sedangkan nilai tertinggi kelas ekperimen adalah 10 dan nilai terendah adalah 6. Dari data tersebut terlihat bahwa rata-rata nilai kelas kontrol adalah 7.29, sedangkan rata-rata nilai kelas eksperimen adalah 7,95. Dengan demikian apabila dilihat dari perbedaan rata-rata nilai post test antara kelas kontrol dengan kelas ekperimen dapat dilihat bahwa ada perbedaan. Untuk mengetahui ada tidaknya perbedaan pengaruh antara kelas kontrol dan kelas ekperimen, maka dilakukan uji $\mathrm{t}$ sebagaimana dibahas pada poin berikutnya.

\section{Uji Beda}

Berdasarkan pada nilai post-test yang diperoleh, untuk mengetahui ada tidaknya pengaruh yang signifikan antara kelas kontrol dengan kelas ekperimen yang menggunakan model pembelajaran tematik-integratif berbasis sosiokultural. Dilakukan uji beda dengan menggunakan uji $t$. Namun sebelum dilakukan uji $t$, perlu dilakukan terlebih dahulu uji prasyarat, yaitu uji normalitas dan homogenitas data. Uji normalitas dan homogenitas data ini berguna untuk melihat apakah data berifat homogen serta normal. Dari hasil uji normalitas data diketahui data sebagaimana ditampilkan pada tabel berikut:

Tabel 2. Uji Normalitas Data

\begin{tabular}{|l|l|l|l|l|}
\hline \multicolumn{2}{|c|}{ Kelas } & \multicolumn{3}{|c|}{ Kolmogorov-Smirnov ${ }^{\mathrm{a}}$} \\
\cline { 3 - 5 } \multicolumn{2}{|c|}{} & Statistic & Df & Sig \\
\hline $\begin{array}{l}\text { Nilai } \\
\text { Post }\end{array}$ & $\begin{array}{l}\text { Kelas } \\
\text { Kontrol }\end{array}$ & .148 & 28 & .118 \\
\cline { 2 - 5 } & $\begin{array}{l}\text { Kelas } \\
\text { Eksperimen }\end{array}$ & .129 & 28 & $.200^{*}$ \\
& & & \\
\hline
\end{tabular}

Berdasarkan pada tabel di atas, maka dapat dilihat bahwa nilai signifikansi untuk nilai kelas kontrol adalah 0.118 sedangkan nilai signifikansi untuk kelas eksperimen adalah 0.200, dengan demikian nilai tersebut lebih besar dari $\alpha=0,05$, maka dari itu dapat disimpulkan bahwa data nilai untuk kelas ekperimen dan kelas kontrol bersifat normal. Selanjutnya selain diuji normalitas, data nilai post test yang diperoleh dilakukan juga uji homogenitas, hasil uji homogenitas data tersebut tertuang pada tabel 3:

Tabel 3. Uji Normalitas Data 


\begin{tabular}{|c|c|c|c|c|c|}
\hline & $\begin{array}{c}\text { Levene } \\
\text { Statisti } \\
\text { c }\end{array}$ & df1 & df2 & Sig. \\
\hline \multirow{4}{*}{$\begin{array}{l}\text { Nilai } \\
\text { Post }\end{array}$} & $\begin{array}{l}\text { Based } \\
\text { on } \\
\text { Mean }\end{array}$ & .934 & 1 & 54 & .338 \\
\hline & $\begin{array}{l}\text { Based } \\
\text { on } \\
\text { Median }\end{array}$ & .754 & 1 & 54 & .389 \\
\hline & $\begin{array}{l}\text { Based } \\
\text { on } \\
\text { Median } \\
\text { and } \\
\text { with } \\
\text { adjuste } \\
\text { d df. }\end{array}$ & .754 & 1 & 47.468 & .390 \\
\hline & $\begin{array}{l}\text { Based } \\
\text { on } \\
\text { trimme } \\
\text { d mean }\end{array}$ & .982 & 1 & 54 & .326 \\
\hline
\end{tabular}

Berdasarkan hasil uji homogenitas data sebagaimana tertuang dalam tabel di atas, maka dapat dilihat bahwa nilai post test kelas kontrol dan kelas eksperimen dilihat dari base on mean menunjukan nilai signifikasni sebesar 0.338, dengan demikian nilai tersebut lebih besar dari $\alpha=0.05$. Maka dari itu, dapat disimpulkan bahwa nilai post-tes kelas eksperimen dan kelas kontrol berisifat homogen.

Untuk mengetahui ada tidaknya perbedaan ketuntasan hasil belajar pada kelas kontrol dan kelas eksperimen digunakan analisis uji-t. Karena data bersifat independent maka digunakan uji-t (independent sample t-test). Dalam penelitian ini perhitungan independent sample t-test menggunakan program SPSS 16.0. Untuk melakukan uji-t sebelumnya diperlukan hipotesis penelitian sebagai berikut.

$\mathrm{H}_{0}$ : Tidak ada perbedaan yang signifikan terhadap ketuntasan hasil belajar antara peserta didik yang mengikuti pembelajaran tematik integratif model umum dengan peserta didik yang mengikuti pembelajaran dengan menggunakan model pembelajaran tematik-integratif berbasis sosiokultural.

$\mathrm{H}_{1}$ : Ada perbedaan yang signifikan terhadap ketuntasan hasil belajar antara peserta didik yang mengikuti pembelajaran tematik integratif model umum dengan peserta didik yang mengikuti pembelajaran dengan menggunakan model pembelajaran tematik-integratif berbasis sosiokultural.

Tabel 4. Uji Beda (Independent Samples Test)

\begin{tabular}{|c|c|c|c|c|c|c|}
\hline & \multicolumn{2}{|c|}{$\begin{array}{l}\text { Levene's } \\
\text { Test for } \\
\text { Equality } \\
\text { of } \\
\text { Variances }\end{array}$} & \multicolumn{3}{|c|}{$\begin{array}{l}\text { t-test for Equality of } \\
\text { Means }\end{array}$} \\
\hline & & $\mathrm{F}$ & Sig & $\mathrm{t}$ & Df & $\begin{array}{c}\text { Sig. } \\
(2- \\
\text { tailed) }\end{array}$ \\
\hline \multirow[b]{2}{*}{ Nilai } & $\begin{array}{l}\text { Equal } \\
\text { variances } \\
\text { assumed }\end{array}$ & .934 & $\begin{array}{r}.33 \\
8\end{array}$ & -2.841 & 54 & .006 \\
\hline & $\begin{array}{l}\text { Equal } \\
\text { variances } \\
\text { not } \\
\text { assumed }\end{array}$ & & & -2.841 & $\begin{array}{r}50.68 \\
5\end{array}$ & .006 \\
\hline
\end{tabular}

Dari data yang ditampilkan pada tabel di atas, maka dapat dilihat bahwa nilai signifikansi pada Sig. (2-tailed) menunjukan nilai 0.006, dengan demikian maka nilai tersebut lebih kecil daripada $\alpha=0.05$. Maka dari itu, dapat disimpulkan bahwa $\mathrm{H}_{\mathrm{o}}$ ditolak. Dengan demikian, maka $\mathrm{H}_{\mathrm{a}}$ diterima. Dengan kata lain dapat dimaknai bahwa terdapat perbedaan yang signifikan antara model pembelajaran yang diterapkan pada kelas kontrol dan kelas ekperimen. 
Berdasarkan hasil uji-t, memang secara statistik terlihat bahwa terdapat perbedaan gain standar hasil belajar antara kelas eksperimen dengan kelas kontrol. Hal ini disebabkan karena dalam kelas eksperimen keseluruhan proses pembelajaran didasarkan pada pembelajaran tematik-integratif yang berbasis sosiokultural. Setiap konsep yang dipelajari selalu diterapkan dalam kondisi yang nyata dan sesuai budaya peserta didik. Hal ini diperkuat lagi dengan penggunaan scientific approach (pendekatan saintifik) dimana kegiatan pembelajaran melibatkan peserta didik secara aktif. Penggunaan pendekatan ini membuat peserta didik semakin terampil untuk menggunakan pengetahuannya dalam situasi praktis dan nyata.

Pembelajaran yang dilakukan pada kelas kontrolmasih berpusat kepada guru, meskipun pembelajaran yang dilaksanakan sudah tematik-integratif namun peserta didik hanya mendengarkan penjelasan guru tanpa ada kegiatan pembelajaran secara nyata. Selain itu, guru juga telah berupaya untuk mengkontekstualkan pembelajaran dengan kondisi nyata, namun upaya ini belum berjalan optimal. Peserta didik belum berpartisipasi secara lebih aktif sehingga dalam hal aplikasi pada situasi praktis rerata nilai peserta didik kelas kontrol belum baik. Dengan demikian dapat disimpulkan bahwa secara total, nilai hasil belajar peserta didik kelas eksperimen lebih baik daripada peserta didik kelas kontrol.

Uji coba yang dilakukan hanya sebatas dua kelas yang terdiri dari masingmasing 28 peserta didik. Hal ini memungkinkan adanya hasil yang berbeda apabila diuji cobakan pada sekala yang lebih luas.

Hasil penelitian tidak dapat digeneralisasikan bahwa model pembelajaran tematik-integratif lebih baik daripada metode yang lain. Namun, dalam penelitian ini sekedar menyampaikan bahwa ada perbedaan pengaruh yang signifikan antara hasil belajar siswa dengan menggunakan model tematik biasa dan model tematik-integratif berbasis sosiokultural.

\section{SIMPULAN}

Berdasarkan hasil penelitian dapat diambil kesimpulan, dilihat dari hasil uji beda antara kelas kontrol dan kelas eksperimen, terdapat perbedaan yang signifikan terhadap hasil belajar antara peserta didik kelas kontrol dan hasil belajar peserta didik kelas eksperimen. Dengan demikian dapat dimaknai bahwa, penerapan model pembelajaran tematik-integratif berbasis sosiokultural memiliki pengaruh yang signifikan terhadap hasil belajar siswa sekolah dasar. 


\section{DAFTAR PUSTAKA}

Allahyar, Negah \& Nazari, Ahmad. (2012). Potentiality of vygotsky's sociocultural theory in exploring the role of teacher perceptions, expectations and interaction strategies. International Journal of Environmental \& Science Education, Vol 4, Halaman 25-28.

Darek, S \& Burns, R. (2004). Meeting standards through integrated curriculum. Alexandria: Association for Supervision and Curriculum Development.

Depdiknas. (2006). Strategi pembelajaran yang mengaktifkan peserta didik. Jakarta: Depdiknas.

Hidayat, Soleh. (2013). Pengembangan kurikulum baru. Bandung: PT. Remaja Rosdakarya

Liu, M. C., Wang, J. Y. (2010). Investigating knowledge integration in web-based thematic learning using. Journal of International Forum of Educational Technology \& Society (IFETS). Vol. 13, No. 2, Hal. 25 -39

Min, K. C., et al. (2012). Teachers' understanding and practice towards thematic approach in teaching integrated living skills (ils) in malaysia. International Journal of Humanities and Social Science, Vol. 2, No. 23.

Schunk H, D. (2012). Learning theories an educational perspective. Boston: Pearson.

Sutarno. (2007). Pendidikan Multikultural. Direktorat Jenderal Pendidikan Tinggi: Departemen Pendidikan Nasional.

Suyanto, Asep Djihad.(2013). Bagaimana menjadi calon guru dan guru profesional. Yogyakarta: Multi Pressindo.

Trianto. 2012. Model Pembelajaran Terpadu. Jakarta: Bumi Aksara 